3 метою розширення можливостей теоретичного опису кислотно-основних і поліконденсаційних рівноваг $y$ водно-силікатних системах, пропонується деяке ускладнення використаної раніше розрахункової моделі. Більи повний облік балансу іонів $H^{+}$дозволяе математичне моделювання структури і фізико-хімічних властивостей водних розчинів не тільки розчинних силікатів, але й кремнієвої кислоти, причому з одним і тим же набором вступних термодинамічних параметрів. В основі модифікованої розрахункової моделі лежить чисельне рішення системи з восьми лінійних і нелінійних рівнянь методом Ньютона.

Нова модель була використана для розрахунку параметрів молекулярно-масового розподілу кремнекисневих частинок $і$ величини рНу водних розчинах кремнієвої кислоти, а також лужних силікатів і силікатів амінів (аміносилікатів). Визначено діапазони значень вхідних термодинамічних параметрів, що дозволяють самоузгоджене опис трьох нетривіальних експериментально спостережуваних ефектів. Це реологічна аномалія у розчинах аміносилікатів, відсутність цієї аномалії в розчинах лужних силікатів $і$ переважно мономірний характер кремнієвої кислоти в низъкоконцентрованному водному розчині кремнезему. Показано, що самоузгодженний опис трьох ефектів є можливим тільки за умови, що сума показників констант дисоціацї ( $\left(K_{a}\right)$ и поліконденсацї $\left(p K_{p}\right)$ силанольної групи менше за 11.6. Для цих розчинів розраховані також концентрації гідролітичних $і$ поліконденсаційних структур в складі аніонів та катіонів, а також проаналізовані залежності цих концентрацій від параметрів розрахункової моделі. Зокрема, показано, що для розчину кремнезему модифікачія розрахункової моделі призводить до значного росту розрахованих значень рН $i$ степеню дисоціацї силанольних груп, у той час як середня ступень полімеризації практично не змінюється. Крім того, виявлено, що у розчинах аміносилікатів ступень деполімеризацї силоксанового зв'язку може немонотонно залежати від величини $\mathrm{pK}_{a}$

Ключові слова: розчинні силікати, силікати амінів, крем'яні кислоти, аномальна реологія, поліконденсація

\section{CALCULATION OF POLYCONDENSATION EQUILIBRIA IN AQUEOUS SOLUTIONS OF SILICA AND SILICATES}

\author{
N. Maliavski \\ $\mathrm{PhD}$, Associate Professor \\ Department of construction materials \\ and materials science \\ National Research Moscow State University \\ of Civil Engineering \\ Yaroslavskoye highway, 26, \\ Moscow, Russia, 129337 \\ E-mail: nikmal08@yandex.ru \\ O. Z huravlova \\ $\mathrm{PhD}$, Deputy Director \\ Corporation «SIIG» \\ Volodymyra Monomakha str., 25-A2, \\ Dnipro, Ukraine, 49000 \\ E-mail: ol.ig.zh@gmail.com
}

\section{Introduction}

Water-soluble silicates (WSS) include silicates of alkali metals (AMS), as well as silicates of quaternary ammonium bases (QAS). In addition, they can also include less trivial compounds, such as silicates with metal complex cations (MCS) and silicates with cations based on protonated amino compounds, or amino silicates (AS). We call aqueous solutions of the first group of WSS liquid glasses, the last three groups are the alkali-free liquid glasses.

Chemical and some physical properties of WSS solutions depend on different processes such as hydrolysis by anion (AS solutions - also by cation) and polycondensation of silicon-oxygen anions (SOA) to a decisive degree. Interdependent hydrolysis and polycondensation equilibria determine the most important structural and chemical characteristics of solutions such as parameters of molar mass distribution of SOA (MMDS), a degree of ionization of silanol groups, a $\mathrm{pH}$ value and many others [1].
One of the most interesting properties of WSS solutions is a rheological anomaly, which consists in reversibly increasing viscosity of a solution at heating in wide ranges of temperatures and solution concentrations [2]. Viscosity of a solution can increase by several orders of magnitude, up to reversible gelatinization of a solution. Researchers found the anomaly in solutions of most AS, as well as in some AMS and MCS solutions [3, 4]. They also found that, at least in AS solutions, the anomaly manifests itself against the background of the displacement of MMDS at heating to higher polymerization levels [2].

The presented study is a continuation of a series of studies on the development of a theoretical model of aqueous WSS solutions in order to explain presence or absence of the rheological anomaly in them in connection with a description of other physicochemical properties. The actual task is creation of a theoretical model capable of describing physicochemical properties of WSS solutions and their precursors - aqueous solutions of silicic acid with the same set of parameters. 


\section{Literature review and problem statement}

Aqueous AS solutions with protonation constants of the amino compound in the range of $10^{-4.5}-10^{-2.8}$ manifest an effect of the rheological anomaly [2,3]. The peculiarities of these solutions are possibility to obtain rather high concentrations of silica (up to $20-25 \%$ by weight) and a thermodynamically equilibrium nature. This makes them closer to solutions of silicates of strong bases (AMS and QAS) and makes possible their joint theoretical description within the framework of unified mathematical models.

There is no rheological anomaly in solutions of silicates of strong bases as a rule. Researchers did not find the anomaly in detailed studies on rheological properties of aqueous solutions of sodium silicates [5], potassium silicates [6] and tetramethylammonium silicates [3]. There are exceptions, which include concentrated aqueous solutions of lithium silicates, but in this case, the rheological anomaly occurs due to a decrease in solubility of a silicate with an increase in temperature [1]. Displacements of MMDS do not accompany such anomaly [3]. The second group of exceptions are solutions of one of MCS, namely, sodium silicate, where a cation of tetramminzinc replaces sodium partially [4]. A nature of the rheological anomaly in the latter case is not yet clear, but it seems that thermodynamic properties of a complex cation play a decisive role in it.

The effect of the rheological anomaly found practical application in several technologies in water-silicate systems. Such as low-temperature production of quartz fiber [2], production of water-resistant mineral heat insulation and application of decorative coatings on glass [7]. This makes the problem of development of a general quantitative theory of the phenomenon extremely urgent. Its resolution could greatly facilitate the search for new and modification of known systems with such an anomaly and expand a scope of its practical application.

There were studies carried out to explain the rheological anomaly and other physicochemical properties of solutions in a context of the universal theoretical model of a silicate solution. In this connection, it is important to note work [8], which shows possibility of a successful description of a water-silicate system with a use of polycondensation equilibrium parameters of SOA, which are independent on a degree of polymerization. Paper [9] is also interesting, as it presents results of an investigation on aqueous solutions of silicates with a use of methods of infrared, Raman, and NMR spectroscopy. Authors did not find a significant dependence of MMDS on a type of a cation in solutions of alkali silicates.

Finally, authors of paper [10] showed possibility of creation of a mathematical model of an aqueous WSS solution of any type except for MCS. The model made it possible to calculate an average degree of polymerization of SOA and $\mathrm{pH}$ value in a solution. Authors used the same approach as in paper [8]. They used experimental parameters of a solution composition only. Such as molar concentrations of silica and cation, and a set of constants, which characterize acid-base and polymerization properties of ions. The basis of the calculation method was reduction of the task of solution of a system of nonlinear equations to a solution of a nonlinear equation by a numerical method of half-division based on reasonable assumptions. The proposed model made possible to explain presence of the rheological anomaly in AS solutions and its absence in solutions of silicates of strong bases.
Several studies dealt with another non-trivial effect related to water-silicate systems. Polycondensation equilibrium parameters regulate it as well. This is a monomeric nature of silicic acid in equilibrium solutions of silica in water. Thus, authors of work [11] confirmed experimentally the monomeric nature of silicic acid in solutions up to a concentration of $\mathrm{SiO}_{2}$, which corresponds to solubility in water of amorphous silica. Authors of paper [12] jumped to the same conclusion for biogenic silica.

Nevertheless, the calculation model used in paper [10] assumed negligible concentrations $\left[\mathrm{H}^{+}\right]$. Therefore, it is applicable to solutions with a strong alkaline medium only. Attempts to apply it to saturated $\mathrm{SiO}_{2}$ solutions in water lead to completely incorrect estimates of the degree of SOA polymerization (a linear polymer instead of a monomer) and $\mathrm{pH}$ value (3.2-3.9 instead of 6.6-6.9). Modification of the calculation model from a paper [10] in the direction of more full accounting of a real balance of $\mathrm{H}^{+}$cations, even at the cost of complication of a calculation process, can be a way to overcome mentioned difficulties and to increase universality of the mathematical model.

\section{The aim and objectives of the study}

The objective of this work is to create a universal mathematical model to ensure that results of calculations are consistent with experimental data on solutions of silicates and silicic acids with any $\mathrm{pH}$ value.

We set the following tasks to achieve the objective:

- modification of the theoretical model of the silicate solution used in [10] for development of a new calculation method and to optimize a process of convergence of the iterative procedure;

- indication of possibility of mathematical modeling of three experimental effects: the rheological anomaly in AS solutions, its absence in AMS and QAS solutions, predominantly monomeric nature of silicic acid in a saturated silica solution;

- verification of possibility of calculation of not only averaged parameters of the MMDS, but also of concentrations of various hydrolysis-polycondensation structures in solutions of silicic acid and silicates with a use of a modified model.

\section{Calculation model: taking into account the} concentration of $\mathrm{H}^{+}$ion and possibility of modification of the model

In this study, we use the same approach to modeling of an aqueous WSS solution as authors in paper [10]. At the same time, changes introduced in the calculation methodology give possibility to improve adequacy of the mathematical model significantly and broaden a scope of its application in a number of important cases. As before, the main object of the description was AS aqueous solution, as the most complex system of the considered ones.

Both models - the one used in paper [10] (model 1) and the modified one (model 2) - assume the thermodynamically equilibrium nature of WSS solution, independence of the dissociation equilibrium constant of silanol groups and the equilibrium constant of a polycondensation reaction of SOA on the degree of polymerization of the latter. Then we can 
record corresponding equilibria and expressions for equilibrium constants as follows:

$$
\begin{aligned}
& K_{a}=\frac{\left[\equiv \mathrm{Si}-\mathrm{O}^{-}\right] \times\left[\mathrm{H}^{+}\right]}{[\equiv \mathrm{Si}-\mathrm{OH}]}, \\
& K_{p}=\frac{[\equiv \mathrm{Si}-\mathrm{O}-\mathrm{Si} \equiv] \times\left[\mathrm{OH}^{-}\right]}{[\equiv \mathrm{Si}-\mathrm{OH}] \times\left[\equiv \mathrm{Si}-\mathrm{O}^{-}\right]} .
\end{aligned}
$$

In addition, there are equilibria of protonation of amino groups with an equilibrium constant in AS solutions:

$$
K_{b}=\frac{\left[\mathrm{R}-\mathrm{NH}_{3}^{+}\right] \times\left[\mathrm{OH}^{-}\right]}{\left[R-\mathrm{NH}_{2}\right]} .
$$

We can record a similar expression for silicates of other weak bases.

A fourth equation, which underlies the calculation model, is the ion product of water:

$$
K_{w}=\left[\mathrm{H}^{+}\right] \times\left[\mathrm{OH}^{-}\right] .
$$

We used a value of basicity of SOA $(x)$ to characterize the degree of «polymerization» of SOA in this study, as in papers [2, 3, 8]. It relates to a more frequently used value of connectivity of $\mathrm{SOA}(Q)$ by the linear relation $x=2-0.5 Q$; and it is more convenient for to characterize highly polymerized silicate structures. $x$ value can vary from zero (crystalline quartz) to two (orthosilicic acid). It is not difficult to show that we can record an average value of SOA basicity in a system by the concentration of siloxane bonds and the total molar concentration of silica in a solution $\left(C_{\mathrm{SiO}_{2}}\right)$ as follows:

$$
x=2-[\equiv \mathrm{Si}-\mathrm{O}-\mathrm{Si} \equiv] / C_{\mathrm{SiO}_{2}} .
$$

Finally, based on considerations of stoichiometry, we obtained three more equations:

$$
\begin{aligned}
& 4 C_{\mathrm{SiO}_{2}}=[\equiv \mathrm{Si}-\mathrm{OH}]+\left[\equiv \mathrm{Si}-\mathrm{O}^{-}\right]+ \\
& +2[\equiv \mathrm{Si}-\mathrm{O}-\mathrm{Si} \equiv], \\
& C_{A}=\left[\mathrm{R}-\mathrm{NH}_{3}^{+}\right]+\left[\mathrm{R}-\mathrm{NH}_{2}\right], \\
& {\left[\equiv \mathrm{Si}-\mathrm{O}^{-}\right]+\left[\mathrm{OH}^{-}\right]=\left[\mathrm{R}-\mathrm{NH}_{3}^{+}\right]+\left[\mathrm{H}^{+}\right],}
\end{aligned}
$$

where $C_{A}$ is a total molar concentration of a silicate-forming cation (in the case of AS AC, it is amino compound).

In order to preserve the generality of the approach, we formally considered equations (3), (7) and (8) also for silicates of strong bases, but only with a very large value of the protonation equilibrium constant $\left(p K_{b}=-3\right)$, which in fact excludes hydrolysis over a cation completely.

For the convenience of calculation, in model 1 a negligible concentration of hydrogen cations compared with the concentration of a silicate-forming cation, was assumed, that is quite acceptable for solutions of silicates with $\mathrm{pH}=10.5-12.5$. Then equation (8) takes the form:

$$
\left[\equiv \mathrm{Si}-\mathrm{O}^{-}\right]+\left[\mathrm{OH}^{-}\right]=\left[\mathrm{R}-\mathrm{NH}_{3}^{+}\right] \text {. }
$$

Now we can reduce the solution of the system of equations (1)-(7), (9) to solution of the nonlinear equation:

$$
Q\left(F+\frac{K_{w}}{K_{a}}\right)-2 x \sqrt{C_{\mathrm{SiO}_{2}}}=0
$$

where the following relations determine values of $Q$ and $F$ parameters:

$$
\begin{aligned}
& Q=\sqrt{\frac{(2-x) K_{a}}{K_{p} K_{w}},} \\
& F=\frac{K_{b}}{2}\left(\sqrt{1+\frac{4 C_{A}}{K_{b}\left(1+Q \sqrt{C_{\mathrm{SiO}_{2}}}\right)}}-1\right) .
\end{aligned}
$$

Authors of paper [10] solved equation (10) by a numerical method of half-division. The fact that the equation always has the only one solution in the admissible interval of $x$ values facilitated it further.

There is no assumption of negligible $\left[\mathrm{H}^{+}\right]$smallness in the modified model (model 2). Therefore, it was not possible to reduce the solution of a system of equations to the solution of a single equation. Therefore, it was necessary to solve a system of eight equations (1)-(8), five of them (1)-(5) were nonlinear equations.

We solved the obtained system (1)-(8) by the widely known Newton method for solution of systems of nonlinear equations. We implemented the method using a specially developed in the programming $\mathrm{C}++$ language $\mathrm{C}$ SISCALC computer program. Testing of the program on test cases showed that we could achieve necessary stability and accuracy of the solution by preliminarily normalizing of input and output parameters, for example, by using logarithms of some of them. In particular, authors of work [13] applied this approach to calculate multicomponent heterogeneous equilibria by the Newton method. Therefore, all unknowns' values except SOA basicity, and all input parameters, except $C_{\mathrm{SiO}_{2}}$ and $C_{A}$ concentrations, participate in equations in a logarithmic form in SISCALC program. Thus, a set of input parameters looks as follows $T=C_{\mathrm{SiO}_{2}}, U=C_{A}, V=\log _{10} K_{w}$, $W=\log _{10} K_{a}, Y=\log _{10} K_{b}, Z=\log _{10} K_{p}$, and a set of variables $x_{0}=x, x_{1}=\log _{10}\left[\mathrm{H}^{+}\right], x_{2}=\log _{10}\left[\mathrm{OH}^{-}\right], x_{3}=\log _{10}[\equiv \mathrm{Si}-\mathrm{OH}]$, $x_{4}=\log _{10}\left[\equiv \mathrm{Si}-\mathrm{O}^{-}\right], x_{5}=\log _{10}[\equiv \mathrm{Si}-\mathrm{O}-\mathrm{Si} \equiv], x_{6}=\log _{10}[A]$, $x_{7}=\log _{10}\left[A^{+}\right]$( $A$ is the non-ionized amino compound, $A^{+}$is the amine-containing cation or a cation of a strong base).

Finally, the system of equations takes the following form:

$$
\begin{aligned}
& x_{0}-2+\frac{10^{x_{5}}}{T}=0 ; \\
& x_{4}+x_{1}-x_{3}-W=0 ; \\
& x_{7}+x_{2}-x_{6}-Y=0 ; \\
& x_{5}+x_{2}-x_{3}-x_{4}-Z=0 ; \\
& 10^{x_{3}}+10^{x_{4}}+2 \cdot 10^{x_{5}}-4 T=0 ; \\
& 10^{x_{6}}+10^{x_{7}}-U=0 ; \\
& 10^{x_{4}}+10^{x_{2}}-10^{x_{7}}-10^{x_{1}}=0 ; \\
& x_{1}+x_{2}-V=0 .
\end{aligned}
$$

We calculated the Jacobians after each iteration during the calculation. We performed an exit from the iterative pro- 
cess after $\mathrm{pH}$ change was less than 0.0001. Less than ten iterations were enough to achieve the required accuracy in all cases. We set zero approximations of variables according to average values of really admissible intervals. We calculated values of equilibrium constants for different temperatures with a use of a special SILSOL subprogram by calculation by the van't Hoff equation. We used experimental or assumed values of enthalpy changes in water dissociation $\left(\Delta H_{w}\right)$, silanol dissociation $\left(\Delta H_{a}\right)$, amine protonation $\left(\Delta H_{b}\right)$ and SOA polycondensation $\left(\Delta H_{p}\right)$ reactions.

\section{Results of calculation of parameters of MMDS and concentrations of hydrolysis- polycondensation structures}

5.1. Selection of values of input parameters and calculation results for the average basicity of SOA

We resolved the system of equations (13) with the SISCALC program for solutions of silica and silicates at $293 \mathrm{~K}$ using values of equilibrium constants and enthalpies of corresponding reactions located at reasonable intervals near the generally accepted values. Thus, $p K_{a}$ value (the generally accepted value for orthosilicic acid is 9.8 [1]), taking into account the latest data [14], varied in the interval $9.8-13.0$ and $\Delta H_{a}-$ in the interval $0-51 \mathrm{~kJ} / \mathrm{mol}$, $p K_{p}$ value (the only experimental value is 0.86 [1]) in the interval $0-10.0$, and $\Delta H_{p}$ value - in the interval $0-15 \mathrm{~kJ} / \mathrm{mol}$. We choose silicates of three characteristic amines for modeling at temperatures of $273-373 \mathrm{~K}$. This is monoethanolamine (EOA, $p K_{b}=4.5, \Delta H_{b}=7.0 \mathrm{~kJ} / \mathrm{mol}$ ), methylamine (MA, $p K_{b}=3.4, \Delta H_{b}=2.7 \mathrm{~kJ} / \mathrm{mol}$ ) and piperidine (PPN, $\left.p K_{b}=2.8, \Delta H_{b}=4.1 \mathrm{~kJ} / \mathrm{mol}\right)$. These amines differ significantly in terms of values of basicity constants, but they exhibit a well-marked rheological anomaly in the $\mathrm{H}_{2} \mathrm{O}-\mathrm{SiO}_{2}-$ amine systems [10].

A representative of AMS for modeling in the framework of SISCALC was the commercial high modulus sodium liquid glass manufactured by Science Company ${ }^{\circledR}$ with $C_{\mathrm{SiO}_{2}}=3.4 \mathrm{~mol} / 1$, molar module 4.9 and $\mathrm{pH}=11.3$ (NAS, $p K_{b}=-3.0$, $\left.\Delta H_{b}=0\right)$. Finally, we used generally accepted values for parameters of the water dissociation process: $p K_{w}=14.0, \Delta H_{w}=57.5 \mathrm{~kJ} / \mathrm{mol}$.

Table 1 shows $x$ and $\mathrm{pH}$ values at $20^{\circ} \mathrm{C}$ in a saturated aqueous solution of silica calculated for 21 sets of input parameters within reasonable ranges of their values. There are calculations carried out for both computational models - the former one and the modified one. We can see clearly that model 1 gives strongly underestimated $\mathrm{pH}$ values, while model 2 is quite real, typical values for a diluted solution of very weak acid.

Table 2 shows the results of calculation of temperature dependences of the average basicity SOA in concentrated aqueous solutions of emethylammonium and sodium silicates with molar silicate modules $\left(N_{S}\right)$ equal to 2.4 and 4.9 , respectively, for model 2.
Table 1

Values of the average basicity of $\mathrm{SOA}$ and $\mathrm{pH}$ at $20^{\circ} \mathrm{C}$ calculated for the solutions of silica $\left(\left[\mathrm{SiO}_{2}\right]=0.0001, N_{S}=2 \cdot 10^{6}\right)$ for two calculated models

\begin{tabular}{|c|c|c|c|c|c|c|}
\hline \multirow{2}{*}{$p K_{p}$} & \multicolumn{3}{|c|}{ Average basicity of SOA } & \multicolumn{3}{|c|}{$\mathrm{pH}$ value } \\
\hline & $p K_{a}=9.8$ & $p K_{a}=10.5$ & $p K_{a}=11.0$ & $p K_{a}=9.8$ & $p K_{a}=10.5$ & $p K_{a}=11.0$ \\
\hline \multicolumn{7}{|c|}{ Model 1} \\
\hline 0.8 & 0.9985 & 1.5308 & 1.7954 & 3.3798 & 3.7054 & 3.8660 \\
\hline 1.0 & 1.1548 & 1.6538 & 1.8618 & 3.3310 & 3.6884 & 3.8620 \\
\hline 1.2 & 1.3120 & 1.7544 & 1.9077 & 3.2870 & 3.6752 & 3.8587 \\
\hline 1.4 & 1.4614 & 1.8315 & 1.9399 & 3.2489 & 3.6655 & 3.8568 \\
\hline 1.6 & 1.5952 & 1.8872 & 1.9614 & 3.2174 & 3.6586 & 3.8557 \\
\hline 1.8 & 7075 & 1.9253 & 1.9751 & 3.1927 & 3.6528 & 3.8543 \\
\hline 2.0 & 1.7954 & 1.9517 & 1.9839 & 3.1737 & 3.6498 & 3.8527 \\
\hline \multicolumn{7}{|c|}{ Model 2} \\
\hline 0.8 & 0.9989 & 1.5306 & 1.7956 & 6.6902 & 6.8536 & 6.9334 \\
\hline 1.0 & 1.1552 & 1.6541 & 1.8614 & 6.6658 & 6.8446 & 6.9324 \\
\hline 1.2 & 1.3122 & 1.7544 & 1.9081 & 6.6438 & 6.8379 & 6.9298 \\
\hline 1.4 & 1.4616 & 1,8313 & 1.9401 & 6.6248 & 6.8330 & 6.9288 \\
\hline 1.6 & 1.5953 & 1.8869 & 1.9614 & 6.6090 & 6.8295 & 6.9281 \\
\hline 1.8 & 1.7074 & 1.9257 & 1.9753 & 6.5966 & 6.8271 & 6.9277 \\
\hline 2.0 & 1.7958 & 1.9518 & 1.9843 & 6.5873 & 6.8254 & 6.9274 \\
\hline
\end{tabular}

Table 2

Values of the average basicity of SOA for solutions of methylammonium silicate (MAS, $\left[\mathrm{SiO}_{2}\right]=4.0, N_{S}=2.4$ ) and sodium silicate (NAS, $\left[\mathrm{SiO}_{2}\right]=3.4, N_{S}=4.9$ )

\begin{tabular}{|l|l|l|l|l|l|l|}
\hline \multirow{2}{*}{$p K_{p}$} & \multicolumn{7}{|c|}{$\mathrm{MAS}$} & \multicolumn{3}{c|}{$\mathrm{NAS}$} \\
\cline { 2 - 7 } & $20{ }^{\circ} \mathrm{C}$ & $50{ }^{\circ} \mathrm{C}$ & $80^{\circ} \mathrm{C}$ & $20{ }^{\circ} \mathrm{C}$ & $50{ }^{\circ} \mathrm{C}$ & $80{ }^{\circ} \mathrm{C}$ \\
\hline \multicolumn{7}{|c|}{$p K_{a}=9,8 ; \Delta H_{a}=14 ; \Delta H_{b}=5 ; \Delta H_{p}=10$} \\
\hline 0.8 & 0.1225 & 0.0933 & 0.0815 & 0.1147 & 0.1274 & 0.1440 \\
\hline 1.0 & 0.1353 & 0.1060 & 0.0933 & 0.1177 & 0.1323 & 0.1509 \\
\hline 1.2 & 0.1499 & 0.1187 & 0.1079 & 0.1206 & 0.1372 & 0.1587 \\
\hline 1.4 & 0.1655 & 0.1343 & 0.1245 & 0.1245 & 0.1431 & 0.1685 \\
\hline 1.6 & 0.1831 & 0.1519 & 0.1440 & 0.1284 & 0.1499 & 0.1792 \\
\hline 1.8 & 0.2017 & 0.1714 & 0.1665 & 0.1323 & 0.1577 & 0.1909 \\
\hline 2.0 & 0.2222 & 0.1938 & 0.1938 & 0.1382 & 0.1665 & 0.2046 \\
\hline \multicolumn{7}{|c|}{$p K_{a}=10.5 ; \Delta H_{a}=30 ; \Delta H_{b}=5 ; \Delta H_{p}=10$} \\
\hline 0.8 & 0.0972 & 0.0854 & 0.0806 & 0.1196 & 0.1255 & 0.1323 \\
\hline 1.0 & 0.1099 & 0.0981 & 0.0942 & 0.1235 & 0.1313 & 0.1401 \\
\hline 1.2 & 0.1235 & 0.1128 & 0.1099 & 0.1294 & 0.1392 & 0.1499 \\
\hline 1.4 & 0.1401 & 0.1304 & 0.1284 & 0.1362 & 0.1489 & 0.1626 \\
\hline 1.6 & 0.1587 & 0.1499 & 0.1499 & 0.1440 & 0.1606 & 0.1782 \\
\hline 1.8 & 0.1802 & 0.1733 & 0.1753 & 0.1548 & 0.1753 & 0.1978 \\
\hline 2.0 & 0.2046 & 0.1997 & 0.2065 & 0.1685 & 0.1929 & 0.2212 \\
\hline \multicolumn{7}{|c|}{$p K_{a}=111.0 ; \Delta H_{a}=30 ; \Delta H_{b}=0 ; \Delta H_{p}=15$} \\
\hline 0.8 & 0.0903 & 0.0776 & 0.0737 & 0.1323 & 0.1431 & 0.1548 \\
\hline 1.0 & 0.1040 & 0.0913 & 0.0884 & 0.1392 & 0.1538 & 0.1694 \\
\hline 1.2 & 0.1206 & 0.1079 & 0.1060 & 0.1489 & 0.1665 & 0.1860 \\
\hline 1.4 & 0.1392 & 0.1274 & 0.1265 & 0.1606 & 0.1831 & 0.2075 \\
\hline 1.6 & 0.1616 & 0.1519 & 0.1528 & 0.1763 & 0.2036 & 0.2349 \\
\hline 1.8 & 0.1880 & 0.1802 & 0.1841 & 0.1938 & 0.2290 & 0.2671 \\
\hline 2.0 & 0.2192 & 0.2144 & 0.2222 & 0.2173 & 0.2603 & 0.3081 \\
\hline
\end{tabular}


We performed calculations for the same sets of silanol dissociation and SOA polymerization constants as in Table 1, as well as for three sets of introductory enthalpy parameters.

The same regularities occur for two other amino silicate solutions. In the silicate solution of the weakest of three bases - monoethanolamine - the anomaly zone is narrower and it has lower intensity, and in the silicate of the strongest base, piperidine, respectively, it is wider and larger. We took $x_{\max } / x_{\min }$ as intensity of the rheological anomaly, where $x_{\max }$ and $x_{\min }$ are, respectively, maximum and minimum $x$ values in the temperature range of the anomaly (usually $\left.20-80{ }^{\circ} \mathrm{C}\right)$.

\section{2. Achievement of the required univer-} salization of the calculation model

As we already noted, the universality criterion of the modified calculation model is its ability to describe three experimentally observed effects with the same set of input parameters:

- presence of the rheological anomaly in AS solutions;

- absence of such anomaly in solutions of silicates of strong bases (AMS and QAS);

- predominantly monomeric nature of silicic acid in stable aqueous solutions of silica with low concentration.

As follows from Table 2, in solutions of sodium silicate for all sets of input parameters, we observe an increase in $x$ (a decrease in the degree of polymerization) is observed with an increase in temperature, which is equivalent to the absence of the rheological anomaly. On the other hand, we observe the rheological anomaly in all considered cases, at least in the most important temperature range of $20-50{ }^{\circ} \mathrm{C}$ in AS solutions. Thus, we can state that the first two criteria for universality of a model are satisfied. As for the third criterion, we should note that monograph [1] states the predominantly monomeric nature of silicic acid $(x \approx 2$, which corresponds to the formula $\mathrm{H}_{4} \mathrm{SiO}_{4}$ ) in a saturated aqueous solution of silica. A number of works confirmed it later, for example, papers [11, 12], although some works contested it [15].

The results of calculations show that the average basicity of SOA increases with increases in $p K_{a}$ and $p K_{p}$, and $\mathrm{pH}$ value increases with an increase in $p K_{a}$ and decreases with an increase in $p K_{p}$ in aqueous solutions of silica. It is interesting that we obtain the same dependences for solutions of silicates of strong bases, while for AS solutions these dependences have a more complex, nonmonotonic character in many cases.

The data from Table 1 show that the fulfillment of the third criterion of universality of the calculation model (the average basicity of SOA in silicic acid $x_{S A} \geq 1.75$ ) is possible only for sufficiently large values of $p K_{a}+p K_{p}$. There is a zone of the third criterion (blue and green fields) represented as a graph in coordinates $p K_{a}-p K_{p}$ on Fig. 1.

The condition $p K_{a}+p K_{p}=11.6$ determines it. There is complete fulfillment of the second criterion of universality in the entire region of the diagram: there is no rheological anomaly in solutions of silicates of strong bases. As for the first criterion - the existence of the rheological anomaly in AS solutions with $p K_{b}=2.8-4.5$ (where they are established experimentally), then its implementation is theoretically possible in the entire region of the diagram for sufficiently large values of $\Delta H_{a}$ and $\Delta H_{p}$.
$\mathrm{pK}_{\mathrm{a}}$

$\begin{array}{llllllllllll}9.8 & 10 & 10.2 & 10.4 & 10.6 & 10.8 & 11 & 11.2 & 11.4 & 11.6 & 11.8 & 12\end{array}$

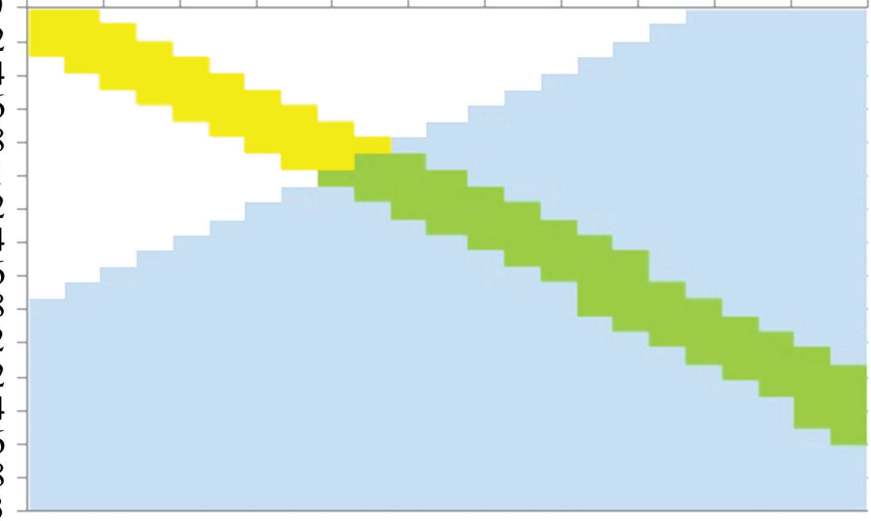

Fig. 1. Zones of fulfillment of universality criteria: green

or $-x_{S A} \geq 1.75$ and $11.2<p H_{W G}<11.4$; blue color $-x_{S A} \geq 1.75$

and $p H_{W G}>11.4$ or $p H_{W G}<11.2$; yellow color $-x_{S A}<1.75$ and

$1.2<p H_{W G}<11.4$; white color $-x_{S A}<1.65$ and $p H_{W G}>11.4$

or $p H_{W G}<11.2$

We investigated the universality of the calculation model with a help of an additional, fourth criterion - the possibility of reproducing of the experimental $\mathrm{pH}$ value of high-modulus liquid glass produced by Science Company ${ }^{\circledR}\left(\left[\mathrm{SiO}_{2}\right]=3.4\right.$, $\left.N_{S}=4.9\right): p H_{W G}=11.3 \pm 0.1$ at $+20^{\circ} \mathrm{C}$. Yellow and green colors indicate the execution zone for this criterion in Fig. 1. Thus, the zone of possible fulfillment of all four criteria of the model universality is the zone painted in green in Fig. 1. Variation of the input values of $\Delta H_{a}$ and $\Delta H_{p}$ showed that the complete fulfillment of the first criterion for all silicate solutions of all amines with $2.8 \leq p K_{b} \leq 4.5$ within this zone is possible only at $\Delta H_{a} \geq 43 \mathrm{~kJ} / \mathrm{mol}$ and $\Delta H_{p} \geq 7 \mathrm{~kJ} / \mathrm{mol}$. This agrees with the boundaries of intervals of reasonable values of both parameters substantiated in paper [10].

\section{3. Calculation of concentrations of hydrolysis-poly-} condensation structures

The solutions of equation (10) and system of equations (13) make it possible to analyze dependences on input parameters of not only $x$ and $\mathrm{pH}$ values, but also other characteristics of hydrolysis and polycondensation processes in the systems under study. Such characteristics, first of all, are molar concentrations of ionized and non-ionized silanol groups, siloxane bonds, and for AS solutions, protonated and not protonated amino groups. We analyzed their dependencies on input parameters $K_{a}$ and $K_{p}$. As an example, Table 3 shows calculated values of concentration indices of three silicate structures for a saturated aqueous solution of silica, assuming $p K_{a}=11.0$ and $p K_{p}$ in the range from 1.05 to 1.35 . It is easy to see that the refinement of the calculated model introduces significant changes in the obtained concentrations $\equiv \mathrm{Si}-\mathrm{O}^{-}, \equiv \mathrm{Si}-\mathrm{OH}$, as well as in $\mathrm{pH}$ values, while the resulting concentrations $\equiv \mathrm{Si}-\mathrm{O}-\mathrm{Si} \equiv$ almost do not change.

It is interesting to note almost complete coincidence of concentrations of $\equiv \mathrm{Si}-\mathrm{OH}$ in model 1 and concentrations of $\equiv \mathrm{Si}-\mathrm{O}^{-}$in model 2 . The reason for this is on the main difference in the calculation models used - in accounting (model 2, equation (8)) or non-accounting (model 1, equation (9)) of the concentration of $\mathrm{H}^{+}$ions in construction of the material balance of cations. 
Table 3

Calculated values of $p C=-\log _{10} C$ for molar concentrations of various silicon-oxygen forms and $\mathrm{pH}$ at $20^{\circ} \mathrm{C}$ in a silica solution $\left(\left[\mathrm{SiO}_{2}\right]=0.0001, p K_{a}=11.0\right)$ for two calculation models

\begin{tabular}{|c|c|c|c|c|c|c|c|c|}
\hline Model & \multicolumn{3}{|c|}{1} & \multicolumn{4}{c|}{2} \\
\hline$p K_{p}$ & 1.05 & 1.15 & 1.25 & 1.35 & 1.05 & 1.15 & 1.25 & 1.35 \\
\hline$\equiv \mathrm{Si}-\mathrm{O}^{-}$ & 10.564 & 10.560 & 10.558 & 10.554 & 3.426 & 3.421 & 3.416 & 3.413 \\
\hline$\equiv \mathrm{Si}-\mathrm{OH}$ & 3.426 & 3.421 & 3.417 & 3.412 & 7.495 & 7.490 & 7.487 & 7.484 \\
\hline$\equiv \mathrm{Si}-\mathrm{O}-\mathrm{Si} \equiv$ & 4.902 & 4.991 & 5.084 & 5.175 & 4.902 & 4.991 & 5.083 & 5.175 \\
\hline $\mathrm{H}^{+}$ & 3.861 & 3.860 & 3.858 & 3.857 & 6.931 & 6.930 & 6.930 & 6.929 \\
\hline
\end{tabular}

As a result, calculation for model 2 , in contrast to model 1 , gives quite real $\mathrm{pH}$ values close to seven, which are typical for a solution of a very weak acid, which is $\mathrm{H}_{4} \mathrm{SiO}_{4}$. This, in turn, explains a sharp increase in the calculated degrees of dissociation of silanol groups: from values of $10^{-7}$ order in model 1 to approximately 1.0 in model 2 .

Thus, almost all silanol groups turn out to be undissociated at using of model 1, and dissotiated at using of model 2. The approximate equality of values of $\left[\equiv \mathrm{Si}-\mathrm{O}^{-}\right]+[\equiv \mathrm{Si}-\mathrm{OH}]$ for identical $p K_{p}$ in both calculation models leads to the effect described above.

We also performed similar calculations for aqueous solutions of AMS and AS with silica concentrations from 1.5 to $5 \mathrm{~mol} 1$ and molar silicate modules from 1 to 5 . In these systems, concentrations of hydrolysis-polycondensation structures are almost identical at use of both computational models. Fig. 2 shows the dependences of three such parameters on $p K_{a}$ and $p K_{p}$ values for an aqueous solution of monoethanolammonium silicate $\left(\left[\mathrm{SiO}_{2}\right]=1.7 ; \mathrm{N}_{\mathrm{S}}=1.13\right)$, which exhibits the pronounced rheological anomaly.

We can see that five of the six curves show the monotonous nature of the dependence on $p K_{a}$ and $p K_{p}$, and the sixth one (curve 1 in Fig. 2, $a$ ) passes through a minimum at $p K_{a} \approx 10.7$.
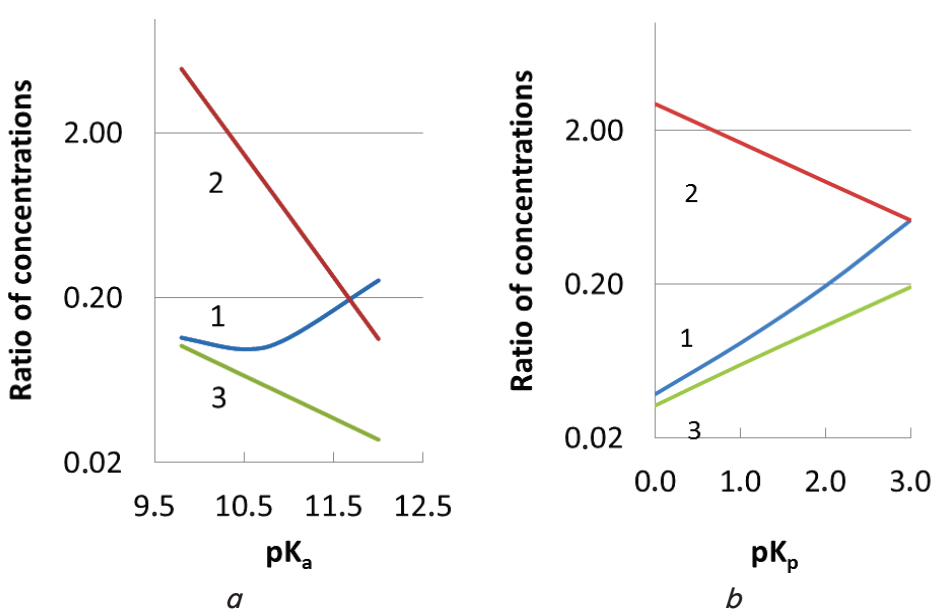

Fig. 2. Calculated dependences of polymerization-hydrolysis parameters of the monoethanolammonium silicate solution: $a-$ on $p K_{a}$ value at $p K_{p}=1.2$ and $b-$ on $p K_{p}$ value at $p K_{a}=10.5$.

Parameters: $1-\left([\equiv \mathrm{Si}-\mathrm{OH}]+\left[\equiv \mathrm{Si}-\mathrm{O}^{-}\right]\right) /[\equiv \mathrm{Si}-\mathrm{O}-\mathrm{Si} \equiv]$, $2-\left[\equiv \mathrm{Si}-\mathrm{O}^{-}\right] /[\equiv \mathrm{Si}-\mathrm{OH}], 3-\left[-\mathrm{NH}_{3}^{+}\right] /\left[-\mathrm{NH}_{2}\right]$

\section{Discussion of results of modeling the chemical and physical-chemical properties of aqueous solutions of silicates}

The calculation model proposed here assumes a full accounting of the balance of $\mathrm{H}^{+}$ions, which makes possible a self-consistent modeling of a structure and properties of aqueous solutions of not only silicates but also silicic acid. As well as the previous one, it correctly reproduces the most important experimentally observed displacements of MMDS with changes in input parameters in silicate solutions. First of all, we mean an increase in $x$ with a decrease in $C_{\mathrm{SiO}_{2}}$ at a constant $C_{A}$, with an increase in $C_{A}$ at a constant $C_{\mathrm{SiO}_{2}}$ and, for silicates of weak bases, with a decrease in $p K_{b}$ at constant $C_{\mathrm{SiO}_{2}}$ and $C_{A}$. We can reproduce less trivial effects also well, for example, an increase in $x$ at diluting of silicate solutions of weak bases. Authors of paper [10] noted this last effect and explained it by the weaker dependence of $\mathrm{pH}$ on a concentration in such solutions, in comparison with solutions of alkaline silicates.

The calculation model developed here made possible to model shifts of MMDS in silica solutions. We can note here, for example, an increase in $x$ at a decrease in $C_{\mathrm{SiO} \text {, }}$ among trivial dependencies. Quite unexpected was the fact that values of the average basicity of SOA in solutions of silicates and silicic acid obtained for model 1 were almost identical to values obtained for model 2.

This is even more surprising because $x_{5}$ value, which affects $x_{0}$ through the first equation in the system (13), appears in two more equations of the system, where $x_{2}, x_{3}$ and $x_{4} \mathrm{pH}$-dependent variables influence it. The observed effect should be the subject of further research.

If we consider the possibility of application of the model to non-silicate systems also, then an increase in $x$ with an increase in $p K_{p}$ in all solutions and an increase in $p K_{a}$ in solutions of salts of strong bases appears to be trivial. Other features of the response of the modified calculation model have no explanation and no experimental confirmation for now. In particular, we are talking about an increase in $x$ and $\mathrm{pH}$ with an increase in $p K_{a}$ in acid solutions (Table 1), a decrease in $x$ with an increase in $p K_{a}$ in a number of cases in solutions of salts of weak bases (Table 2). 
We determined a number of regularities in a result of calculations of concentrations of hydrolysis-polycondensation structures in solutions of silicates and silicic acid. In particular, we found out that there is a regular decrease in $[\equiv \mathrm{Si}-\mathrm{O}-\mathrm{Si} \equiv]$ (due to a growth of $\left[\equiv \mathrm{Si}-\mathrm{O}^{-}\right]+[\equiv \mathrm{Si}-\mathrm{OH}]$ ) and a slight decrease in $\mathrm{pH}$ (Table 3 ) with a decrease in a tendency toward polycondensation (with an increase in $p K_{p}$ ). This latter effect occurs due to an increase in $\mathrm{H} / \mathrm{Si}$ molar ratio in silicic acids with a decrease in the degree of their polymerization.

In all systems, the degree of dissociation of silanol groups decreases with an increase in $p K_{p}$ at a constant $p K_{a}$ and with an increase in $p K_{a}$ at a constant $p K_{p}$. As for the depolymerization index $\left([\equiv \mathrm{Si}-\mathrm{OH}]+\left[\equiv \mathrm{Si}-\mathrm{O}^{-}\right]\right) /[\equiv \mathrm{Si}-\mathrm{O}-\mathrm{Si} \equiv]$, it always increases with an increase in $p K_{a}$ in solutions of alkali silicates. It can monotonically increase, monotonically decrease or show a nonmonotonic dependence (Fig. 2, $a$ ) in solutions of silicates of weak bases. In all likelihood, a complex nature of the dependence of the index of depolymerization on input parameters is due to the fact that variables, which make up the index $\left(x_{3}, x_{4}\right.$ and $\left.x_{5}\right)$, belong the largest number of equations in the system (13). Finally, the degree of protonation of amino groups $\left[-\mathrm{NH}_{3}{ }^{+}\right] /\left[-\mathrm{NH}_{2}\right]$ increases with a decrease in $p K_{a}$ at constant $p K_{p}$ and with an increase in $p K_{p}$ at constant $p K_{a}$ in solutions of all AS.

None of the models used is capable of describing one more non-trivial experimentally confirmed effect related to thermodynamic and rheological properties of aqueous solutions of silicates. We mean an increase in the degree of polymerization of SOA and viscosity of highly concentrated AS solutions with an increase in the amine concentration at the constant silica concentration [10]. It seems that a quantitative description of the effect will be possible if we will take into account coefficients of activity of interacting species, for example, by using the method of Pitzer. Researchers applied it successfully to model silicate solutions $[16,17]$.

Another direction of the improvement of the calculation model is inclusion of thermodynamic properties of metal complex cations in consideration for the theoretical description of aqueous solutions of MCS. As noted above, researchers found out the existence of a very intense rheological anomaly at least in one of such systems. There is a high probability that there are other similar systems, and theoretical modeling would give possibility to develop criteria for their search. Finally, an important achievement in the development of the theoretical model would be inclusion of solutions of lithium silicates with the rheological anomaly, possibly at the cost of complication of the model and an increase in a number of input parameters.

In general, an increase in a number of solutions with the rheological anomaly would expand possibilities for the practical application of alkali-free liquid glasses significantly. We can name synthesis of adsorbents with controlled porosity, creation of protective coatings on metals and, finally, production of aerogels of complex composition based on water-soluble precursors among possible new directions of their use.

\section{Conclusions}

1. We proposed a modification of the previously used mathematical model for calculation of structural and physicochemical parameters of aqueous solutions of silicates. The essence of the modification is a full complete accounting of the balance of $\mathrm{H}^{+}$cations formed during dissociation of water and silanol groups, as well as during the hydrolysis of silicate-forming cations. The input parameters of the model are concentrations of silica and a silicate-forming cation, equilibrium constants of dissociation of water and a silanol group, polycondensation of the latter, and hydrolysis of a cation, as well as changes in enthalpy in the course of the same processes. The practical application of the modified model to a specific silicate solution leads to a system of eight linear and nonlinear equations numerically solved by the Newton method. The solution makes it possible to determine the most important parameters of MMDS in solution, $\mathrm{pH}$ value and a degree of hydrolysis of a cation of a weak base. Due to adequate consideration of a real ionic composition of the solution, the model gives possibility to describe quantitatively a structure and properties of not only strongly alkaline but also neutral and slightly acidic solutions of silicates and silicic acids.

2. We obtained a self-consistent quantitative description of three nontrivial experimentally observed effects: a rheological anomaly in AS solutions, absence of the anomaly in solutions of AMS and QAS, predominantly monomeric nature of silicic acid in a saturated aqueous solution of silica. In this case, we used a single set of input parameters within the intervals of reasonable values: generally accepted ones $\left(K_{w}, \Delta H_{w}\right)$, values based on experimental data $\left(K_{a}, K_{p}\right)$ or values obtained by interpolation of values of corresponding parameters of chemical analogs $\left(\Delta H_{a}, \Delta H_{p}\right)$. The obtained result is important not only because we achieved the maximum universality of the model (properties of solutions of three types of WSS are described), but also because it gave us the theoretical description of the third of the above effects.

3 . We calculated concentrations of hydrolysis-polycondensation structures for solutions of silicic acid, AS and AMS: $\equiv \mathrm{Si}-\mathrm{OH}, \equiv \mathrm{Si}-\mathrm{O}^{-}, \equiv \mathrm{Si}-\mathrm{O}-\mathrm{Si} \equiv$, and for solutions of AS, amine in free form and protonated form. We analyzed dependences of these concentrations and their ratios on values of input parameters of the calculation model $\left(p K_{a}\right.$ and $\left.p K_{p}\right)$. We showed the possibility of a nonmonotonic dependence of the average degree of polymerization SOA on $K_{a}$ value in solutions of silicates of weak bases. We also found that the modification of the calculated model could lead to a sharp change in a calculated degree of dissociation of silanol groups, even in those cases when it almost does not cause a shift in MMDS.

\section{References}

1. Iler R. K. The Chemistry of Silica. Wiley, 1979. 886 p.

2. Maliavski N., Tchekounova E., Dushkin O. Silica fibers obtained from aminosilicate solutions with a reversible spinnability // Journal of Sol-Gel Science and Technology. 1994. Vol. 2, Issue 1-3. P. 503-505. doi: https://doi.org/10.1007/bf00486298

3. Malyavskiy N. I., Pokid'ko B. V. Polikondensacionnye ravnovesiya i reologicheskaya anomaliya v vodnyh rastvorah silikatov // Internet-vestnik VolgGASU. Ser.: Politematicheskaya. 2013. Issue 4 (29). URL: http://vestnik.vgasu.ru/attachments/MalyavskiyPokidko-2013_4(29).pdf 
4. Toutorski I. A., Tkachenko T. E., Maliavski N. I. Structural and chemical modification of polydiene latexes by gel derived silica // Journal of Sol-Gel Science and Technology. 1998. Vol. 13, Issue 1-3. P. 1057-1060. doi: https://doi.org/10.1023/a:1008628919412

5. Yang X., Zhu W., Yang Q. The Viscosity Properties of Sodium Silicate Solutions // Journal of Solution Chemistry. 2008. Vol. 37, Issue 1. P. 73-83. doi: https://doi.org/10.1007/s10953-007-9214-6

6. Yang X., Zhang S. Characterizing and Modeling the Rheological Performances of Potassium Silicate Solutions // Journal of Solution Chemistry. 2016. Vol. 45, Issue 12. P. 1890-1901. doi: https://doi.org/10.1007/s10953-016-0540-4

7. Malyavskiy N. I. Shchelochnosilikatnye utepliteli. Svoystva i himicheskie osnovy proizvodstva // Rossiyskiy himicheskiy zhurnal. 2003. Issue 4. P. 39-45.

8. Characterizing the Infrared Bands of Aqueous Soluble Silicates / Falcone Jr. J. S., Bass J. L., Krumrine P. H., Brensinger K., Schenk E. R. // The Journal of Physical Chemistry A. 2010. Vol. 114, Issue 7. P. 2438-2446. doi: https://doi.org/10.1021/jp908113s

9. Controlling the reactivity of silicate solutions: A FTIR, Raman and NMR study / Vidal L., Joussein E., Colas M., Cornette J., Sanz J., Sobrados I. et. al. // Colloids and Surfaces A: Physicochemical and Engineering Aspects. 2016. Vol. 503. P. 101-109. doi: https:// doi.org/10.1016/j.colsurfa.2016.05.039

10. Maliavski N., Zhuravlova O., Denysiuk O. The rheological anomaly in water-silicate systems: a possible thermodynamic explanation // Eastern-European Journal of Enterprise Technologies. 2017. Vol. 4, Issue 6 (88). P. 23-28. doi: https:// doi.org/10.15587/1729-4061.2017.105837

11. Silicic acid polymerization in hydrothermal solution / Gorbach V. A., Potapov V. V., Kashpura V. N. et. al. // Proceedings, 31st Workshop on Geothermal Reservoir Engineering. SGP-TR-179. Stanford, California, 2006.

12. Belton D. J., Deschaume O., Perry C. C. An overview of the fundamentals of the chemistry of silica with relevance to biosilicification and technological advances // FEBS Journal. 2012. Vol. 279, Issue 10. P. 1710-1720. doi: https://doi.org/10.1111/ j.1742-4658.2012.08531.x

13. Nichita D. V. New unconstrained minimization methods for robust flash calculations at temperature, volume and moles specifications // Fluid Phase Equilibria. 2018. Vol. 466. P. 31-47. doi: https://doi.org/10.1016/j.fluid.2018.03.012

14. Shields G., Seybold P. Computational Approaches for the Prediction of pKa Values. CRC Press, 2013. 175 p. doi: https:// doi.org/10.1201/b16128

15. Alvarez R., Sparks D. L. Polymerization of silicate anions in solutions at low concentrations // Nature. 1985. Vol. 318, Issue 6047. P. 649-651. doi: https://doi.org/10.1038/318649a0

16. Weber C. F., Hunt R. D. Modeling Alkaline Silicate Solutions at $25^{\circ} \mathrm{C} / /$ Industrial \& Engineering Chemistry Research. 2003. Vol. 42, Issue 26. P. 6970-6976. doi: https://doi.org/10.1021/ie0303449

17. Modeling Speciation in Highly Concentrated Alkaline Silicate Solutions / Provis J. L., Duxson P., Lukey G. C., Separovic F., Kriven W. M., van Deventer J. S. J. // Industrial \& Engineering Chemistry Research. 2005. Vol. 44, Issue 23. P. 8899-8908. doi: https://doi.org/10.1021/ie050700i 